\title{
INNOWACYJNE PRZEOBRAŻENIA KRAJOBRAZU WSI - CZYNNIKI I EFEKTY
}

Zarys treści: Bardzo rzadko zmiany krajobrazu wynikają z potrzeb, wymagań czy preferencji społeczności lokalnych. Często koncepcje zagospodarowania przestrzennego terenu wykonywane są przez specjalistów, którzy oczywiście konsultują efekty swojej pracy z mieszkańcami, ale nadal pomysły są twórczym wyrazem projektantów, a nie bezpośrednich użytkowników danej przestrzeni.

W niniejszej pracy autorka pragnie ukazać innowacyjny sposób procesu projektowego prowadzący do nowatorskich zmian w krajobrazie wiejskim. Cel ten jest realizowany etapowo. Najpierw wyjaśniono pojęcie innowacyjności (by w jego rozumieniu ująć studium przypadku), a następnie wskazano wyzwania i problemy rozwoju obszarów wiejskich, które są potrzebą innowacyjnych zmian. Następnie wskazano na czynniki inicjujące i warunkujące innowacyjne przeobrażenia krajobrazu wsi, gdyż w nich należy upatrywać podstaw odmiany, by w końcu ukazać efekty innowacyjnych przeobrażeń krajobrazu wsi, będące skutkiem warsztatów facylitacyjnych przeprowadzonych w 2017 roku w wybranych dwóch wsiach gminy Krobia (województwo wielkopolskie), tj. Pudliszki i Domachowo.

Słowa kluczowe: czynniki przeobrażeń wsi, efekty zmian krajobrazu wsi, innowacyjne projektowanie.

\section{Wprowadzenie}

Proces przeobrażeń krajobrazu wsi miał charakter dualistyczny, tzn. z jednej strony człowiek dążył do podporządkowania przyrody swoim utylitarnym interesom, z drugiej zaś podejmował działania na rzecz ochrony bogactwa, piękna i osobliwości naturalnych form (Chmielewski 2001). W rozwoju historycznym można wyróżnić kilka faz przemian krajobrazowych: okres duchowego kształtowania krajobrazu (ok. 16 tys. lat temu), okres wyspowego przekształcania krajobrazu (ok. 9 tys. lat temu), okres strefowego przekształcania krajobrazu (okres średniowieczny), okres wielkoprzestrzennego przekształcania krajobrazu i wyspowego skażenia środowiska (okres renesansu), okres globalnych przekształceń i strefowych skażeń środowiska (wiek XX) (Szafer 1965; Leńkowa 1978; Rylke 1978; 
Meadows i in. 1992; Chmielewski 2001). W związku z tymi zmianami rozpoczęto działania na rzecz ochrony przyrody i krajobrazu (Wolski, Piwowarski 1998), zwracano uwagę na wzbogacanie różnorodności biologicznej i krajobrazowej, harmonizowanie gospodarki z funkcjonowaniem krajobrazowych systemów ekologicznych i ogólną proprzyrodniczą zmianą modelu życia człowieka (Kalinowska 1993; Chmielewski 2009). Na początku XXI wieku tematyka prac naukowych dotyczyła często ekologii krajobrazu, praktycznych analiz przestrzennych (analiza obiektowa, badania przepływów materii i energii, analiza struktury krajobrazu metodami geomatyki) (Żarska 2006; Skalski 2007; Lechio i in. 2008). Dopiero w połowie lat 20. XXI wieku zaczęto mówić o innowacyjnym przeobrażaniu krajobrazu wsi w różnych jego wymiarach (Knieć 2010; Nowakowska 2011; Wyszkowska 2012; Czapiewska 2014; Zrobek 2014; Zajda 2015): terytorialnym, społecznym, przestrzennym i ekonomicznym.

W wyniku wielu decyzji administracyjnych, czasem politycznych, także gospodarczych, krajobraz wsi ulegał i ulega przekształceniom. Bardzo rzadko zmiany te wynikają z potrzeb, wymagań czy preferencji społeczności lokalnych. Często koncepcje zagospodarowania przestrzennego terenu wykonywane są przez specjalistów, którzy oczywiście konsultują efekty swojej pracy z mieszkańcami, ale nadal pomysły są twórczym wyrazem projektantów, a nie bezpośrednich użytkowników danej przestrzeni (Staszewska 2013).

W niniejszej pracy autorka chce ukazać innowacyjny sposób procesu projektowego, który może doprowadzić do innowacyjnych zmian. Dlatego pierwsza część pracy odnosi się do czasu przeszłego (bowiem etap projektowy już się odby1), druga część ma odniesienie do czasu przyszłego, bowiem przekształcenia w krajobrazie wsi jeszcze nie nastąpiły (rozpoczął się dopiero cykl decyzji, organizacji, finansowania i realizacji). Aby jednak przybliżyć empiryczną część pracy, najpierw wyjaśniono pojęcie innowacyjności (by w jego rozumieniu ująć studium przypadku), a następnie wskazano wyzwania i problemy rozwoju obszarów wiejskich, które są potrzebą innowacyjnych zmian. Następnie wskazano na czynniki inicjujące i warunkujące innowacyjne przeobrażenia krajobrazu wsi, gdyż w nich należy upatrywać podstaw odmiany, by w końcu ukazać efekty innowacyjnych przeobrażeń krajobrazu wsi, będące skutkiem warsztatów facylitacyjnych przeprowadzonych w 2017 roku w wybranych dwóch wsiach gminy Krobia (województwo wielkopolskie).

\section{Znaczenie innowacji w procesie ksztaltowania obszarów wiejskich}

Innowacyjność jest terminem pochodnym w stosunku do pojęcia innowacja. Formułowanie precyzyjnych stwierdzeń na temat innowacyjności, zarówno w kontekście jej poziomu, jak i determinant wymaga więc przyjęcia określonej definicji innowacji. Innowacyjność jako cecha charakteryzująca podmioty może być 
rozumiana na dwa sposoby. Pierwsze podejście utożsamia ją z określoną postawą, charakteryzującą się kreatywnością, otwartością na zmiany lub też skłonnością do ryzyka. W podejściu drugim akcentuje się skutki ilościowe działalności pewnych organizacji (np. samorządów lokalnych), np. w postaci liczby wdrożonych innowacji w danym okresie. W tym ujęciu innowacyjność utożsamiana jest z aktywnością oraz z efektywnością innowacyjną. Współcześnie realizowane projekty innowacyjne nie są efektami spontanicznych odkryć utalentowanych jednostek, ale wynikiem programowanych, zakrojonych na szeroką skalę przedsięwzięć, ukierunkowanych na osiągnięcie określonego celu społecznego, przestrzennego czy gospodarczego. Tym samym wdrażanie innowacji postrzegane jest dziś jako proces, którym można sterować i poprzez odpowiednie bodźce stymulować jego przebieg (Bielski 2000; Chodyński 2013).

Obszary wiejskie są kształtowane w wyniku ciągłego postępu cywilizacyjnego, który obfituje często w innowacyjne rozwiązania technologiczno-organizacyjne. Osiągnięcie właściwego poziomu rozwoju terytorialnego wymaga wykorzystania środków i instrumentów umożliwiających ciągły postęp. Wprowadzanie innowacji przestrzennych na terenach wiejskich daje możliwość poprawy warunków zamieszkania mieszkańców, wzrostu ich pozadomowej aktywności i mobilności. Innowacyjne rozwiązania w gospodarce wsi mogą wpłynąć na tworzenie nowych miejsc pracy, poprawę warunków życia społeczności lokalnej, zaspokajanie jej potrzeb, wzrost liczby podmiotów i poprawę przedsiębiorczości. To niewątpliwie może wpłynąć na osiąganie wzrostu konkurencyjności poszczególnych jednostek przestrzennych (Żukrowska 2000; Zrobek 2014). Urzeczywistnienie wytyczonych celów prorozwojowych wymaga więc przyjęcia odpowiedniego kierunku postępowania oraz sprawnej realizacji działań.

W opracowaniu innowacyjność potraktowano jako korzystną (lub niekorzystną) zmianę w obrębie przestrzennych i społecznych procesów kształtowania wsi. Przy czym dla uznania zmiany za innowację nie jest wymagane, aby była ona nowością na skalę światową; warunkiem wystarczającym jest nowość dla wdrażającego ją podmiotu. Równocześnie nie musi to być zmiana radykalna. Innowacjami zatem określono przypadki zmian przełomowych i zaskakujących, a także zmiany ewolucyjne o charakterze usprawniającym.

\section{Wyzwania i problemy rozwoju obszarów wiejskich potrzebą innowacyjnych zmian}

Wielu badaczy zajmujących się rozwojem obszarów wiejskich przewiduje zmiany w ich sposobie zagospodarowania i zarządzania. Według nich nastąpi: wzrost dochodów ludności wiejskiej oraz poprawa życia kulturalnego mieszkańców wsi, nieracjonalne gospodarowanie gruntami, zanieczyszczenie środowiska spowodowane lokalizacją uciążliwych zakładów przemysłowych oraz wskutek rozwoju 
funkcji turystycznej, zróżnicowanie funkcjonalne obszarów wiejskich (Falkowski 2014; Jezierska-Töle, Biczkowski 2014), dwu- i wielozawodowość w rolnictwie, zróżnicowanie dochodów ludności wiejskiej, rozdrobnienie struktury agrarnej, zmiana sytuacji bytowej mieszkańców wsi (Wójcik 2013), inicjowanie własnych przedsięwzięć gospodarczych, często pozarolniczych, restrukturyzacja i transformacja społeczno-gospodarcza przestrzeni wiejskiej (Falkowski 2015), nastąpią też zmiany demograficzne i infrastrukturalne (Rydz, Rudnicki 2009).

W związku z powyższym, do najważniejszych wyzwań i problemów rozwoju obszarów wiejskich, które mają wpływ na przeobrażenia ich krajobrazu należą:

a) społeczne:

- likwidacja dysproporcji w poziomie rozwoju i warunkach życia ludności,

- zapewnienie mieszkańcom dostępu do infrastruktury społecznej - miejsc pracy, nauki i odpoczynku, usług (głównie usług zdrowia, handlu, oświaty, kultury),

- zapewnienie mieszkańcom dostępu do infrastruktury technicznej,

- niedostateczna liczba miejsc aktywności społecznej,

- zagwarantowanie bezpieczeństwa publicznego;

b) gospodarcze:

- problemy finansowe mieszkańców i samorządów lokalnych,

- problemy związane z uzyskiwaniem większej efektywności ekonomicznej i racjonalnym wykorzystaniem zasobów przez samorządy lokalne,

- rozwój nowych dziedzin życia społecznego i gospodarczego;

c) administracyjne:

- pogodzenie interesów własnych samorządów i inwestycyjnych (inwestora zewnętrznego),

- właściwa organizacja administracyjno-realizacyjna,

- trudności procesu inwestycyjnego wynikające z zarządzania rozwojem obszarów wiejskich zgodnie z prawem minimalizacji wysiłku,

- brak zintegrowanego planowania przestrzennego;

d) prawne:

- trudności wynikające z niestabilności i niespójności przepisów prawa,

- trudności wynikające $\mathrm{z}$ nieuregulowanych stosunków własnościowych (w procesie inwestycyjnym);

e) przestrzenne:

- dekapitalizacja struktury wiejskiej - potrzeba jej rewitalizacji, rehabilitacji, humanizacji i restrukturyzacji,

- trudności komunikacyjne (niedostateczna dostępność komunikacyjna, duże natężenie ruchu, niska jakość dróg, niewystarczająca ilość miejsc parkingowych, niewydolny transport publiczny lub jego brak, hałas),

- degradacja środowiska przyrodniczego, zanieczyszczenie powietrza, konflikt z przyrodą, zbytnie rozproszenie sieci osadniczej wskutek ochrony środowiska przyrodniczego, 
- pozyskiwanie nowych i odzyskiwanie zniszczonych lub zanieczyszczonych terenów pod budownictwo mieszkaniowe,

- budowa lub rozbudowa elementów struktury i związane z tym problemy inżynieryjno-techniczne oraz konieczność zachowania jedności architektonicznej,

- fragmentacja przestrzeni wskutek zmniejszania powierzchni działek budowlanych, wskutek zmiany użytkowania terenu, przekształceń terenów rolnych i leśnych, zagospodarowania terenów dysfunkcyjnych,

- brak terenów pod nową zabudowę mieszkaniową, usługi ogólnodostępne i usługi specjalne (oczyszczalnie, spalarnie, składowiska), pod zieleń i tereny sportu, wypoczynku i rekreacji, pod tereny inwestycyjne,

- uciążliwości wynikające ze zbyt intensywnej zabudowy i zagospodarowania terenu (hałas, zanieczyszczenia).

Jak widać istnieje duża potrzeba działań, które wesprą rozwój obszarów wiejskich. Nadszedł jednak czas na działania nietypowe i niestandardowe, inicjujące proces zmian. Mieszkańcy wsi są zmęczeni przedsięwzięciami ${ }^{1}$, w których biorą udział, a które nie przynoszą wymiernych efektów w poprawie ich warunków życia. Często sami inicjują zadania, składają projekty uzyskując finansowanie

${ }^{1}$ Wnioski wysnuto w oparciu o własne doświadczenia autora podczas wielu przeprowadzonych konsultacji społecznych odbytych w trakcie realizacji licznych projektów przy współpracy:

- z Krajową Siecią Obszarów Wiejskich (KSOW), Fundacją Programów Pomocy dla Rolnictwa (FAPA), Fundacją na Rzecz Rozwoju Polskiego Rolnictwa (FDPA);

- z Polską Siecią Odnowy i Rozwoju Wsi (PSORW);

- z Komisją Obszarów Wiejskich Polskiego Towarzystwa Geograficznego (KOW PTG);

- z władzami 49 gmin miejsko-wiejskich i wiejskich województw: pomorskiego, kujawsko-pomorskiego, podkarpackiego, śląskiego, opolskiego, dolnośląskiego, lubuskiego i wielkopolskiego;

- z Departamentem Rolnictwa i Rozwoju Wsi Urzędu Marszałkowskiego Województwa Wielkopolskiego;

- z Departamentem Programów Rozwoju Obszarów Wiejskich Urzędu Marszałkowskiego Województwa Lubuskiego;

- z Śląskim Związkiem Gmin i Powiatów (siedziba w Katowicach);

- z kadrą naukową Polskiej Akademii Nauk (Warszawa), Instytutu Rozwoju Miast (Kraków), Uniwersytetu Łódzkiego (Łódź), Uniwersytetu Wrocławskiego (Wrocław), Uniwersytetu Przyrodniczego (Wrocław), Politechniką Gdańską (Gdańsk) w prowadzeniu prac projektowo-badawczych i udział w licznych projektach w zakresie odnowy i rozwoju wsi przy współudziale samorządów gmin miejsko-wiejskich i wiejskich; oraz przy projektach finansowanych z Europejskiego Funduszu Rolnego na Rzecz Rozwoju Obszarów Wiejskich: Europa inwestująca w obszary wiejskie jako koordynatorzy lub współrealizatorzy oraz w konferencjach zarządzanych przez Instytucję Zarządzającą PROW 2014-2020 - Ministra Rolnictwa i Rozwoju Wsi pełniąc rolę ekspercką lub doradczą lub jako PARTNER w projektach o znaczeniu społeczno-gospodarczym. 
swoich przedsięwzięć. Jak wiadomo beneficjenci często sięgają po środki ministerialne oferowane zgodnie z art. 57a, pkt 2 Ustawy z dnia 20 lutego 2015 roku o wspieraniu rozwoju obszarów wiejskich z udziatem środków Europejskiego Funduszu Rolnego na rzecz Rozwoju Obszarów Wiejskich w ramach Programu Rozwoju Obszarów Wiejskich na lata 2014-2020² (wcześniej z PROW 2007-2013). Realizacja PROW 2017-2013 oraz 2014-2020 związana była i jest m.in. z innowacją w rolnictwie, ze zwiększeniem rentowności gospodarstw rolnych, ochroną i wzmacnianiem ekosystemów, efektywnym gospodarowaniem zasobami oraz promowaniem rozwoju gospodarczego. Efektem realizacji tych celów jest zmiana w sposobie zagospodarowania, aktywność gospodarcza, zwiększona ruchliwość przestrzenna mieszkańców. Każdy wymieniony projekt inicjuje zmianę w krajobrazie wsi lub ją warunkuje ${ }^{3}$.

\section{Czynniki inicjujące i warunkujące innowacyjne przeobrażenia krajobrazu wsi}

Czynniki to zespół cech, stanów i zjawisk o charakterze przestrzennym, gospodarczym, społecznym, historycznym, kulturowym, prawnym, administracyjnym oraz przyrodniczym, mający istotny wpływ na zakres, formę i tempo zmian w krajobrazie obszarów wiejskich. Przez pojęcie czynników rozumie się także uwarunkowania, a więc warunki wyznaczające (warunki konieczne) lub umożliwiające (warunki wystarczające) zaistnienie określonego zjawiska, stanu rzeczy, stosunku, cechy itp. albo też zwiększające jego prawdopodobieństwo (warunek sprzyjający). Często przez pojęcie warunku rozumie się przyczynę, a więc sprawczy i pierwszy człon związku przyczynowo-skutkowego (Staszewska 2013).

W tej części analizę czynników ujęto w dwóch zbiorach, jako czynniki zewnętrzne (pozamiejscowe, ogólne), inicjujące proces zmian w krajobrazie oraz jako czynniki wewnętrzne (miejscowe, lokalne) warunkujące przebieg i kierunki rozpatrywanego procesu. Stają się one równocześnie czynnikami przekształceń krajobrazu obszarów wiejskich. Treści tych zbiorów usystematyzowano następnie według charakteru czynników. Należy zaznaczyć, że czynniki nie są innowacyjne. To raczej ich wpływ może mieć skutki innowacyjnych zmian.

Uznano, że do najważniejszych czynników zewnętrznych (pozamiejscowych), mających wpływ na zmianę w krajobrazie obszarów wiejskich należą: system gospodarki przestrzennej oraz przepisy prawne, trendy i doktryny urbanistyczno-architektoniczne, a także przemiany gospodarcze kraju.

Obecny system gospodarki przestrzennej w Polsce, działający zgodnie z przepisami prawa, utrudnia zdaniem autorki prowadzenie polityki przestrzennej na terenach wiejskich. Niespójne prawo, ciągłe poszukiwanie przez samorządy

\footnotetext{
${ }^{2}$ Dz.U., 2017, poz. 562, z późn. zm.

${ }^{3}$ www.ksow.pl.
} 
środków finansowych, zahamowanie rozwoju metodologii planowania i warsztatu planistycznego, ułomność rynku nieruchomości powodują, że w procesie zarządzania $\mathrm{w}$ jednostkach samorządu terytorialnego dochodzi do wielu problemów przestrzennych i społecznych. Wskutek tego pojawił się na ich terenach: nieład architektoniczny i przestrzenny, szybko narastająca dewastacja zasobów dziedzictwa kultury materialnej i środowiska przyrodniczego, utrwalanie niekorzystnych podziałów własnościowych gruntów budowlanych w obszarach zurbanizowanych, spekulacja gruntami i nieefektywne wykorzystywanie terenów, niekontrolowane zabudowywanie wzdłuż głównych dróg, nienadążanie z realizacją infrastruktury technicznej za rozwojem zabudowy, pogłębianie się polaryzacji społecznej i przestrzennej, wyludnianie się wsi, braki w wyposażeniu terenów $\mathrm{w}$ infrastrukturę techniczną, pogarszanie się dostępności do infrastruktury społecznej (Staszewska 2013).

Natomiast obowiązujące przepisy prawne, formułujące zasady kształtowania przestrzeni wsi, tj. Ustawa z dnia 27 marca 2003 roku o planowaniu i zagospodarowaniu przestrzennym ${ }^{4}$, nie pozwalają na realizację procesu planowania. Brakuje ustaleń dotyczących przygotowania terenu pod planowane zagospodarowanie, poczynając od scalenia i powtórnego podziału terenów prywatnych, poprzez prawo pierwokupu gminy, aż do dzierżawy nieruchomości i tworzenia gminnych zasobów gruntów. Brakuje określenia zasad i procedur stosowania partnerstwa publiczno-prywatnego, nie są sprecyzowane instrumenty dotyczące finansowania inwestycji w gminie (podatki, pożyczki, subwencje udzielane przez gminę). Brakuje też sprawnego nadzoru urbanistycznego na każdym etapie procesu inwestycyjnego. Polskie władze gminne nie mają też obowiązku uzbrajania terenu pod zabudowę (uruchamianego procedurą planistyczną). Rady gminy nie precyzują wysokości opłat adiacenckich, zasad współdziałania sektora prywatnego, rekompensat ekologicznych od inwestorów z tytułu ochrony środowiska i ochrony przyrody. Ponadto polskie prawo planistyczno-decyzyjne nie ustala zasad prowadzenia polityki terenowej (Ossowicz, Zipser 2006). Gmina powinna prowadzić aktywne działania mające na celu kształtowanie podaży terenów na różne rodzaje użytkowania, ustalone w planach zagospodarowania przestrzennego, przepisy prawne niestety uniemożliwiają czynności tego typu.

Wpływ na kształt, rozmieszczenie i układ elementów zagospodarowania przestrzeni osiedli wiejskich zlokalizowanych na obszarach wiejskich, mają także trendy i doktryny urbanistyczno-architektoniczne. Wyznaczają one kierunek i tendencje w projektowaniu, dzięki którym przestrzeń, którą użytkujemy staje się estetyczna, funkcjonalna, bezpieczna i czytelna. We współczesnym projektowaniu urbanistyczno-architektonicznym zwraca się szczególnie uwagę na zależność

\footnotetext{
${ }^{4}$ Dz.U., 2003, nr 80, poz. 717, z późn. zm.
} 
ładu przestrzennego i ładu urbanistycznego5. Obecnie, chcąc zachować i tworzyć w przestrzeni ład przestrzenny i urbanistyczny, a więc wpływać na logikę i harmonię zagospodarowania, bierze się pod uwagę: 1) reguły gry inwestycyjnej, dzięki której powstają wartości kulturowe i ekonomiczne wpływające na życie jednostki i społeczeństwa, 2) relacje i interakcje ośrodka osadniczego z otoczeniem, 3) właściwości przestrzeni, które wynikają z potrzeb, preferencji i wymagań klientów tej przestrzeni, 4) zasady współrządzenia, zasady gry, uczestników tej gry, obowiązki i kompetencje decydentów, 5) możliwości dostrajania form materialnych przestrzeni do zmieniających się potrzeb i funkcji życiowych, 6) urbanistyczny metabolizm, czyli fazy degradacji tkanki (morfologii) i metody jej ożywienia (Staszewska 2013). Dotychczasowe trendy i doktryny urbanistyczno-architektoniczne oraz nowe podejście do projektowania urbanistycznego niewątpliwie wpływają na kształt osiedli wiejskich. Obecnie zwraca się większą uwagę na potrzeby człowieka, na funkcjonalność przestrzeni, jej użyteczność, bezpieczeństwo i większą możliwość kontaktów społecznych. Z drugiej strony brak środków finansowych często uniemożliwia realizacje projektów.

Czwartym z wymienionych czynników zewnętrznych są przemiany gospodarcze kraju. Te obecne mają wpływ na migracje, co powoduje rozwój funkcji mieszkaniowej i usługowej. W strukturze gmin wiejskich pojawiły się obszary inwestycyjne, zlokalizowane najczęściej wzdłuż głównego układu transportowego. Powstały obszary osiedli mieszkaniowych, oddalone nierzadko od centrum wsi, połączone z istniejącą strukturą jedynie siecią ulic podstawowych i umiejscawiane w pobliżu większych kompleksów zieleni. Na obszarach wiejskich nowa działalność gospodarcza często nie harmonizuje z istniejącym mieszkalnictwem. Władze gminy czasem nawet „faworyzują" pojawiających się przedsiębiorców (zwłaszcza dużych firm) spełniając ich warunki kosztem mieszkańców.

Omówione powyżej czynniki nazwano zewnętrznymi, bowiem są to uwarunkowania pozamiejscowe. Choć oddziaływują one bezpośrednio na przestrzenny rozwój obszarów wiejskich, to nie zależą od lokalnych warunków. Inicjują one proces zmian w krajobrazie wsi, dają początek przemianom wewnętrznym wiejskiej przestrzeni.

Do istotnych czynników wewnętrznych (miejscowych, lokalnych), mających wpływ na zmianę w krajobrazie wiejskim, należą: warunki środowiska przyro-

${ }^{5}$ Definiując ład przestrzenny, T. Zipser (2006) wymienia cechy spójnej i zorganizowanej struktury urbanistycznej, są to: estetyczny wygląd zewnętrzny, przejrzysty (zapamiętywalny i zrozumiały) oraz niezawodny i skuteczny układ, który nie powinien zawierać elementów samodestrukcji. Jednakże pojęcie ładu przestrzennego i ładu urbanistycznego, aczkolwiek mocno ze sobą związane, nie są tożsame. Ład urbanistyczny to współzależność zachodząca między wzorcami życia miejskiego a logiką formy urbanistycznej, pomiędzy formą przestrzenną a procesem społecznym, to harmonizowanie struktur przestrzennych i form życia miejskiego oraz wyważanie racji (uzgadnianie i koordynowanie interesów) różnych podmiotów, działających w przestrzeni zurbanizowanej (Zuziak 2008). 
dniczego, zarządzanie przestrzenne i zarządzanie strategiczne, możliwości finansowania zadań gminnych, udział społeczności lokalnej w procesie planowania, a także potrzeby społeczne i aktywności społeczne.

Pierwszym z wymienionych czynników są zasoby środowiska przyrodniczego, a zwłaszcza: warunki klimatyczne i aerosanitarne, zasoby wodne, zasoby glebowe, wielkoprzestrzenne formy ochrony przyrody oraz fauna i flora. Warunki klimatyczne mają znaczący wpływ na zróżnicowanie warunków zamieszkania na obszarach wiejskich, różnorodna jest bowiem wilgotność powietrza, temperatura powietrza, ciśnienie atmosferyczne oraz prędkość wiatru. Warunki naturalne, tj. rzeźba terenu, klimat i warunki glebowe decydują o doborze terenów pod zabudowę mieszkaniową, wpływają zatem na kierunek, wielkość i intensywność zagospodarowania danego terenu. Rzeźba terenu, a raczej znaczne jego rozrzeźbienie, daje możliwość lepszego komponowania budynków niż na płaskim terenie, umożliwia ciekawe kształtowanie wnętrz osiedlowych i interesujące wiązania ukształtowania terenu z zielenią. Urozmaicony układ terenu wzbogaca efekt przestrzenny zabudowy, utrudnia jednak prowadzenie ulic, uzbrojenie w infrastrukturę itp. Bardzo duży wpływ na kształt i formę terenów wiejskich mają również zasoby wód powierzchniowych i podziemnych. Ich ilość i jakość warunkuje zaopatrzenie obszaru w wodę pitną dobrej jakości oraz podejmowanie wszelkiej działalności produkcyjnej i usługowej (Fagiewicz 2010). To ma swoje odzwierciedlenie w zagospodarowaniu obszaru, w funkcjach czy w intensywności zabudowy. Ponadto są zasobem istotnym dla rozwoju zabudowy mieszkaniowej i zagospodarowania turystycznego (zwłaszcza turystyki krajoznawczej) (Kowalczyk, Derek 2010), ważnym dla mieszkańców z punktu widzenia wartości krajobrazowych, estetycznych, dydaktycznych, rekreacyjnych i turystycznych. Tereny zasobne w wody powierzchniowe są miejscem aktywności człowieka, m.in. spacerów, jazdy na rowerze, wędkarstwa i żeglarstwa.

Czynnikiem istotnym dla krajobrazowego przekształcenia obszarów wiejskich jest zarządzanie przestrzenne. Wykorzystuje ono wiedzę z zakresu ekonomicznej analizy przestrzennej, teorii gospodarki przestrzennej oraz analizy rynków nieruchomości, co prowadzi do umiejętnego wskazania optymalnego użytkowania każdego fragmentu przestrzeni, a także sposobów i dróg transformacji funkcji na tych fragmentach. Opiera się na analizach i oszacowaniu kosztów i korzyści, jakich można by się spodziewać w wyniku przekształceń funkcji planistycznych. Jest to bardzo ważne w przypadku precyzowania kierunków rozwoju obszarów wiejskich gminy, zwłaszcza przy opracowywaniu dokumentu studium uwarunkowań i kierunków zagospodarowania przestrzennego (Bajerowski 2003).

Zarządzanie strategiczne wpływa na rozwój wsi poprzez kompleksowy, nastawiony na formułowanie i wdrażanie strategii rozwoju proces zarządzania (Griffin 1998). Proces ten odbywa się na trzech poziomach: strategicznym, taktycznym i operacyjnym. Na poziomie strategicznym rozwiązuje się najogólniejsze 
problemy rozwoju, przyjętekierunki działań są wówczas zgodne z wyzwaniami strategii rozwoju regionalnego. Na poziomie taktycznym zespół zarządzający opracowuje programy i ustala długookresowe cele i zadania w zakresie wdrażania programu. Na ostatnim, trzecim poziomie, następuje integracja nowych form działalności $\mathrm{z}$ istniejącymi, na tym etapie podejmowane są działania w zakresie planowania i realizacji programu (Crow, Bozeman 1998). Zarządzanie strategiczne należy traktować zatem jako proces podejmowania decyzji i ich realizacji, w których nacisk kładzie się na te wpływające na charakter i kierunek rozwoju danej jednostki terytorialnej.

Oprócz zarządzania przestrzennego i strategicznego, decydujący wpływ na rozwój obszarów wiejskich mają możliwości finansowania przyjętych przez władze gminy zadań. Obecnie władze samorządowe, wobec ogromu i złożoności zadań (które precyzuje Ustawa o samorządzie gminnym ${ }^{6}$ ) w warunkach nadwyżki siły roboczej oraz niekorzystnych tendencji ekonomicznych i ograniczeń budżetowych, muszą pozyskiwać dodatkowe środki, zwłaszcza inwestycyjne. Również wykorzystanie kierunkowego wsparcia wielu fundacji i funduszy $w$ formie dofinansowania, kredytów i pożyczek z dopłatami agencji rolnych, a przede wszystkim najbardziej liczących się obecnie zagranicznych środków pomocowych stwarza szansę finansowania wielostronnego rozwoju, stanowiąc podstawy trwałego sukcesu nie tylko gospodarczego i społecznego, ale także przestrzennego (Główka 2010). W obecnych czasach jednostki samorządu lokalnego działają na granicy opłacalności. Wydatki budżetu jednostki samorządu terytorialnego określone w uchwale budżetowej na kolejny rok mogą być wyższe niż dochody tego budżetu powiększone o nadwyżkę budżetową z lat ubiegłych i wolne środki, jedynie o kwotę związaną z realizacją zadań ze środków z UE. Oznacza to, że wszelkie inwestycje, inne niż związane z projektami UE, będą trudniejsze do realizacji, gdyż nie będzie możliwe zaplanowanie na nie deficytu i zadłużanie się samorządów. Taka sytuacja trwa już od ponad 12 lat (Kopańska, Witkowski 2003). Możliwości prawidłowego (zbilansowanego) działania inwestycyjnego na terenach wiejskich oczywiście jest wiele. Samorządy mogą wykorzystać kredyt kupiecki i factoring, mogą przenieść inwestycje do spółek komunalnych, mogą skorzystać z partnerstwa publiczno-prywatnego czy koncesji. Istnieje jednak niebezpieczeństwo, że mogą one być wykorzystywane niewłaściwie. Wprawdzie formalnie dług będzie poza samorządem, jednak faktyczne ryzyko finansowe będzie spoczywać na nim. Samorządom w realizacji zadań nie jest zatem łatwo, muszą planować przemyślanie i rozważnie, co oczywiście uwidoczni się w przyszłości w zagospodarowaniu przestrzennym obszarów wiejskich.

Ważnym czynnikiem przeobrażeń krajobrazu wsi jest udział społeczeństwa w procesie planowania. W zespole osób decydujących o rozwoju obszarów wiejskich powinni się znaleźć:

${ }^{6}$ Dz.U., 1990, poz. 594. 
- mieszkańcy wsi/gminy,

- podmioty prowadzące lub zamierzające prowadzić na obszarze gminy działalność gospodarczą,

- podmioty prowadzące lub zamierzające prowadzić na obszarze gminy działalność społeczną,

- pracownicy różnych jednostek organizacyjnych samorządu terytorialnego,

- przedstawiciele władzy publicznej, zwłaszcza kadra zarządzająca,

- przedstawiciele organizacji pozarządowych,

- pracownicy naukowo-badawczy, pełniący rolę ekspertów w procesie decyzyjnym.

Wymienione powyżej grupy uzyskują innowacyjne pomysły dzięki współpracy, która opiera się na następujących czynnościach: 1) informowaniu - to najprostsza forma kontaktu, która choć angażuje obywateli w bardzo niewielkim stopniu, to jednak może się przyczynić do akceptacji lub jej braku w momencie podejmowania innowacyjnych decyzji, 2) konsultowaniu - to forma kontaktu, która rozbudowana o metody i narzędzia partycypacyjno-konsultacyjne pozwala na zwiększony udział obywateli w prowadzonych działaniach, daje im możliwość wypowiedzenia się na temat planowanych przedsięwzięć. Osoby uczestniczące w konsultacjach występują niejako w roli „doradców”. Głosy obywateli są rozważane i oceniana jest ich przydatność w procesie zmian, 3) współdecydowaniu - to forma kontaktu, dzięki której dochodzi do dyskusji. Na tym etapie przyjmuje się pewne rozwiązania, przekazywane są kompetencje i kształtowana jest odpowiedzialność, obywatele mają realny wpływ na dotyczące ich (bezpośrednio lub pośrednio) planowane działania ${ }^{7}$.

Wszystkie wymienione czynności prowadzą do sformułowania zadań i potrzeb społeczności lokalnej, pomagają w określeniu priorytetów rozwoju wsi, pozwalają na zdefiniowanie projektów, wspomagają w podjęciu decyzji związanych z kształtem i funkcjonowaniem wsi. Jeśli się przyjmie, że ustalone przedsięwzięcia wpłyną na ożywienie obszaru wiejskiego, będą one prowadzone w sposób zintegrowany w sferze społecznej, przestrzennej, gospodarczej, technicznej i środowiskowej, będą też zmierzać do stworzenia warunków dla bezpiecznego życia, wypoczynku i inwestowania, wpłyną na aktywizację mieszkańców wsi, to niewątpliwie będą one innowacyjne. $Z$ uwagi na obecne problemy polskich wsi (patrz podrodział powyżej), każda korzystna zmiana w obrębie przestrzennych i społecznych procesów kształtowania wsi powinna być uważana za innowacyjną.

Ostatnimi z omówionych tu wewnętrznych czynników przeobrażeń krajobrazu wsi są potrzeby społeczne i aktywności społeczne. Należą one do miejscowych czynników, bowiem wynikają z lokalnych warunków życia i zamieszkania. W literaturze przedmiotu potrzeby społeczne dzieli się na trzy grupy (Lisowski 2006):

${ }^{7} \mathrm{~W}$ literaturze wymienione czynności określane są jako piramida partycypacji (Łuszczek, Ptasińska (red.) 2010; Pawłowska 2010). 
potrzeby przyrodnicze (do których zaspokajania jesteśmy zmuszeni), potrzeby kulturowe (związane z zasadami współżycia społecznego) i potrzeby organizacyjne (które są skutkiem dążenia do realizacji celów społeczeństwa). Powyższe potrzeby nie wpływają jednak na wielkość terenów zainwestowanych i na różnorodność poszczególnych rodzajów użytkowania (funkcji). To potrzeby fizjologiczne, edukacyjne, zdrowotne, duchowe, żywienia, komunikacji i przemieszczania się, samorealizacji i potrzeby przyjemnych doznań zmysłowych mają swoje odniesienie w krajobrazie wiejskim. Te z kolei tworzą strefy funkcjonalno-przestrzenne w przestrzeni, strukturę niezwykle przemieszaną, rozdrobnioną, mniej czy bardziej ekstensywną. Zaspokojenie potrzeb wpływa zatem na zmiany w sposobie zabudowy i zagospodarowaniu terenów wiejskich. Oczywiście oprócz potrzeb, wpływ na przestrzenny układ, na typ zabudowy mieszkaniowej i jej intensywność, mają także warunki fizyczno-geograficzne miejsca, dotychczasowe zainwestowanie, wiek i geneza jednostki osadniczej oraz czynniki technologiczne (możliwości inżynieryjno-techniczne budowy lub rozbudowy elementów struktury, stosowane materiały i technologie w budownictwie), jednakże zawsze kształt, wielkość i forma przestrzeni zurbanizowanej zależeć będzie od psychospołecznych uwarunkowań. Realizacja (zaspokajanie) potrzeb społecznych jest zatem psychologiczno-społecznym czynnikiem zmian toczącego się procesu przeobrażeń krajobrazu wsi.

Potrzeby społeczne, stając się podstawą aktywności społecznych, wykazują związek z procesem zmian w przestrzeni wsi. Niektóre z aktywności są podejmowane z konieczności, w sposób mechaniczny czy wręcz bezmyślny, inne zaś są wynikiem z góry zaplanowanego działania odbywającego się w zależności od wielu istniejących warunków. Każda aktywność wyzwala potrzebę odpowiedniego zagospodarowania, właściwych form urbanistycznych, ilości i jakości krajobrazu. Człowiek odgrywa więc szczególną rolę w kształtowaniu przestrzeni wiejskiej. W wyniku swojej działalności wpływa on na zmianę w jej strukturze, uzupełnia ją, rozbudowuje, poprawia.

Omówione czynniki zewnętrzne i wewnętrzne inicjują i warunkują innowacyjne przeobrażenia krajobrazu wsi. Ta innowacyjność uwidacznia się:

- w ilości i rozmieszczeniu elementów zagospodarowania,

- w organizacji, funkcjonalności zagospodarowania, w predyspozycjach inwestycyjnych obszaru oraz preferencjach jego użytkowników,

- w zdolności poszczególnych części obszaru wiejskiego do przyjęcia różnych form aktywności,

- w ilości i rodzajach relacji (powiązań, kontaktów) wewnętrznych (w ramach osiedla wiejskiego) i zewnętrznych (z innymi ośrodkami),

- w tożsamości i społecznym znaczeniu miejsc w przestrzeni,

- w rezultatach podjętych przez władze samorządowe działań związanych z zagospodarowaniem przestrzennym oraz związanych z pozyskaniem inwestorów, 
- w cechach estetycznych oraz naturalnych i kulturowych składowych krajobrazu,

- w stopniu doskonałości elementów zagospodarowania przestrzeni i zdolności zaspokojenia potrzeb użytkowników danej przestrzeni.

Wyszczególnione powyżej cechy przestrzeni, a więc jej dobra organizacja, funkcjonalne i estetyczne zagospodarowanie, spójność z otoczeniem, zapewnienie aktywności i różnorodności kontaktów społecznych, zachowanie wartości kulturowych, a co najważniejsze - zaspokojenie potrzeb użytkowników powinny być efektem decyzji mieszkańców. Oczywiście zaangażowanie i włączenie ludzi w proces projektowy nie jest łatwe. Często nie wierzą oni w swoje możliwości i umiejętności twórcze, nie są przekonani, aby ich decyzje mogły być zobowiązujące dla władz gminy, boją się projektować, bo brak im wiedzy technicznej. To jednak ich nie dyskwalifikuje. Należy uczestników warsztatów włączyć w proces projektowy poprzez dyskusję, znaleźć odpowiednią technikę graficznej prezentacji ich pomysłów, wspomóc decyzje projektowe fachowym komentarzem lub wyjaśnieniem.

Uczestnictwo w tym twórczym procesie różnych grup społecznych daje możliwość wymiany poglądów i wzbogaca dyskusję w oparciu o istniejące uwarunkowania. Niestety, owo zaangażowanie mieszkańców w projektową formułę nie jest w Polsce często stosowane. Wymaga zastosowania metody opartej na wyznaczeniu nadrzędnych ram działania m.in. poprzez dialog, odpowiednią metodykę spotkań i dyscyplinę tempa pracy. Taką metodą jest facylitacja, która ma na celu wspieranie procesu budowania relacji i procesów rozwojowych poprzez umożliwienie członkom grupy aktywny udział w zdefiniowaniu ram i reguł współpracy tak, aby planowany rozwój odbywał się w optymalnych warunkach. Efekty przeprowadzonego procesu tą metodą prezentują przykłady studium przypadku ujęte w niniejszym artykule.

\section{Efekty innowacyjnych przeobrażeń krajobrazu wsi - studium przypadku}

W tej części artykułu zaprezentowano pozytywne efekty innowacyjnych przeobrażeń krajobrazu dwóch wsi gminy Krobia leżących w województwie wielkopolskim: Pudliszki i Domachowo. Nie są one jeszcze w pełni zrealizowane, ale na uwagę zasługuje niebywała chęć zaangażowania mieszkańców w zmiany. Często utożsamiali się oni z miejscem, powstałą funkcją, wyrażali nadzieję na realizację przedsięwzięć. Propozycje przeobrażeń wymienionych miejsc wynikały głównie z ewolucyjnych zmian o charakterze usprawniającym. Innowacyjność polegała na kreatywności, twórczości i wiedzy uczestników procesu projektowego oraz umiejętności połączeń wielu funkcji na terenach obecnie niezagospodarowanych, a nawet zdegradowanych. Wyróżnione miejsca borykają się z wieloma problemami przestrzennymi, ekonomicznymi, środowiskowymi, pomiędzy które wpleciony jest społeczny nurt potrzeb. Te innowacyjne zmiany mogą wpłynąć nie tylko 
na przeobrażenia krajobrazu, ale przede wszystkim mogą poprawić warunki zamieszkania i życia mieszkańców.

Miejscowość Pudliszki położona jest w odległości około $3 \mathrm{~km}$ na zachód od Krobi, leży na lewym brzegu Polskiego Rowu (prawego dopływu Baryczy), na Wysoczyźnie Leszczyńskiej. Jedna z głównych ulic miejscowości (Poniecka) wyznacza dwie części miejscowości. Zachodnia jest bardziej zaniedbana, wymagająca modernizacji infrastrukturalnych, ale posiadająca duży potencjał przestrzeni publicznych o znaczeniu społecznym, rekreacyjnym i sportowym. Teren ten zamieszkuje 888 osób, a jego powierzchnia wynosi 298 ha). Część północna jest bardziej zurbanizowana, ma zwięzłą strukturę opartą na zabudowie jednorodzinnej i wielorodzinnej, z licznymi uliczkami dojazdowymi (liczba ludności wynosi 1404 osób, powierzchnia 599 ha). Obszar ten zamyka od wschodu zakład produkcyjny Heinz.

Szczególnym miejscem rozważań, ukazującym innowacyjne poczynania projektowe i decyzje społeczno-administracyjne, jest teren w zachodniej części miejscowości. Należy zaznaczyć, że Pudliszki Zachód doświadczają problemów społecznych wynikających z wysokiego poziomu ubóstwa, braku aktywności społecznej, przestępczości i bezrobocia. Do zjawisk kryzysowych występujących na obszarze Pudliszki Zachód należą :

- brak dobrze zorganizowanych miejsc o wysokich walorach turystycznych i wypoczynkowo-rekreacyjnych,

- brak miejsc wypoczynku, rekreacji i spędzania czasu wolnego,

- widoczna duża uciążliwość funkcjonalno-organizacyjna (duży ruch, brak miejsc parkingowych) związana z działalnością firmy Heinz,

- brak miejsc integracji i umożliwiających aktywność pozadomową mieszkańców,

- niska jakość przestrzeni publicznych, brak miejsc spotkań,

- brak obszaru hierarchicznie ważnego, identyfikowalnego społecznie (brak rynku, głównego placu),

- konieczność lepszej organizacji, doinwestowania i remontu terenów i obiektów sportowych,

- trudne warunki dla aktywizacji zawodowej i gospodarczej mieszkańców w związku z funkcjonowaniem dużego zakładu produkcyjnego,

- widoczne braki w doinwestowaniu ścieżki rowerowej łączącej Pudliszki z Krobią (brak oświetlenia, brak miejsc odpoczynku dla podróżujących), co obniża warunki turystyczno-poznawcze gminy i negatywnie wpływa na jakość życia mieszkańców dojeżdżających do wspomnianych miejscowości,

- niska samoocena, brak optymizmu i chęci aktywności u osób starszych, wymagających opieki i dostępu do usług zdrowia,

${ }^{8}$ Wnioski z Diagnozy stanu i kierunków rozwoju gminy Krobia wykonane w ramach opracowania Lokalnego Programu Rewitalizacji Gminy Krobia na lata 2015-2022, wykonawca: Sylwia Staszewska, rok realizacji: 2017). 
- niski poziom wykształcenia seniorów + ,

- niski poziom kondycji psychicznej i fizycznej seniorów+,

- izolacja i samotność osób starszych - brak integracji międzypokoleniowej,

- niedostateczny dostęp do oferty kulturalnej i krajoznawczej,

- widoczne trudności opiekuńcze i zdrowotne z osobami starszymi, niepełnosprawnymi lub zagrożonymi wykluczeniem społecznym.

Prezentowane zjawiska kryzysowe, występujące na obszarze Pudliszki Zachód, uwidoczniły konieczność działań naprawczych we wszystkich sferach życia. Potrzeba tu inwestycji prospołecznych, utworzenia miejsc integracji, wykorzystania potencjału tkwiącego $\mathrm{w}$ istniejących terenach poprzemysłowych i powyrobiskowych. Takim miejscem, które posiada potencjał rozwojowy stała się nieczynna już cegielnia, są tu bowiem dogodne warunki na cele edukacyjne, społeczne, rekreacyjne i gospodarcze. W jej obrębie występują kopalniane wyrobiska po wydobyciu gliny - obecnie zalane wodą. Jest to teren o bardzo zróżnicowanej rzeźbie i dużych różnicach wysokości, mocno przekształcony w wyniku prowadzonej działalności (fot. 1, 2). Wokół wyrobisk niezagospodarowany teren (nieużytki), z zielenią nieurządzoną (porośnięty trawami i zielenią wysoką - drzewa i krzewy). W obrębie przedmiotowego terenu zlokalizowany jest zespół budynków i obiektów budowlanych, będących obecnie w bardzo złym stanie technicznym, są to: gumownia drewniana (budynek parterowy), suszarnie drewniane (trzy budynki parterowe) (fot. 3), kotłownia (budynek parterowy), wyrobownia (budynek dwukondygnacyjny), suszarnia murowana (budynek dwukondygnacyjny), obudowa pieca z piecem i kominem (budynek dwukondygnacyjny) (fot. 4), budynek socjalny (budynek dwukondygnacyjny), hydrofornia (budynek parterowy), budynek mieszkalno-biurowy (parterowy z poddaszem użytkowym), budynek gospodarczy (budynek parterowy), infrastruktura przemysłowa (torowiska, place składowe). W obrębie terenu inwestycji przebiegają także dwie linie energetyczne. Teren jest uzbrojony, a dojazd zapewniony.

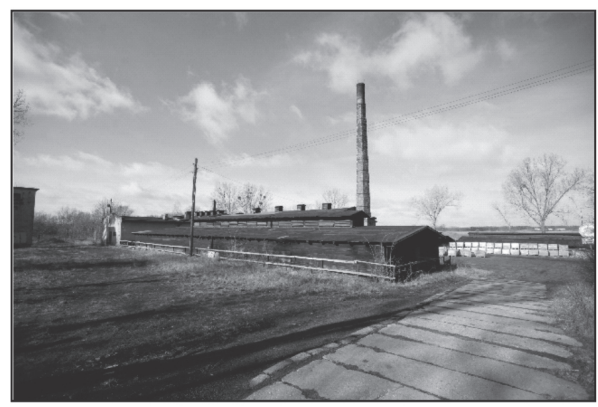

Fot. 1. Cegielnia w miejscowości Pudliszki, widok na centralnie usytuowany piec wraz z budynkami funkcjonalnymi

fot. S. Staszewska

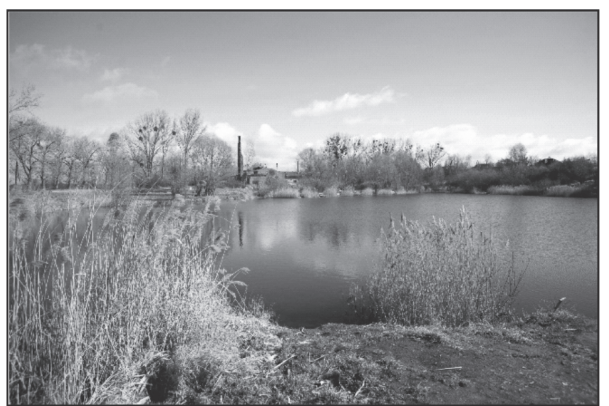

Fot. 2. Powyrobiskowy zbiornik wodny w miejscowości Pudliszki, zlokalizowany na terenie starej cegielni

fot. S. Staszewska 


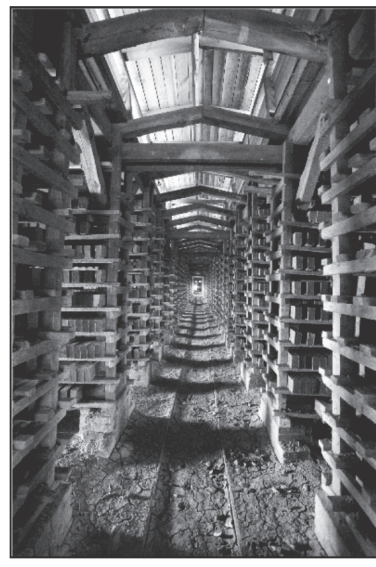

Fot. 3. Cegielnia w miejscowości Pudliszki, widok na wnętrze suszarni wraz z pozostawionymi tam niewypalonymi cegłami

\section{fot. S. Staszewska}

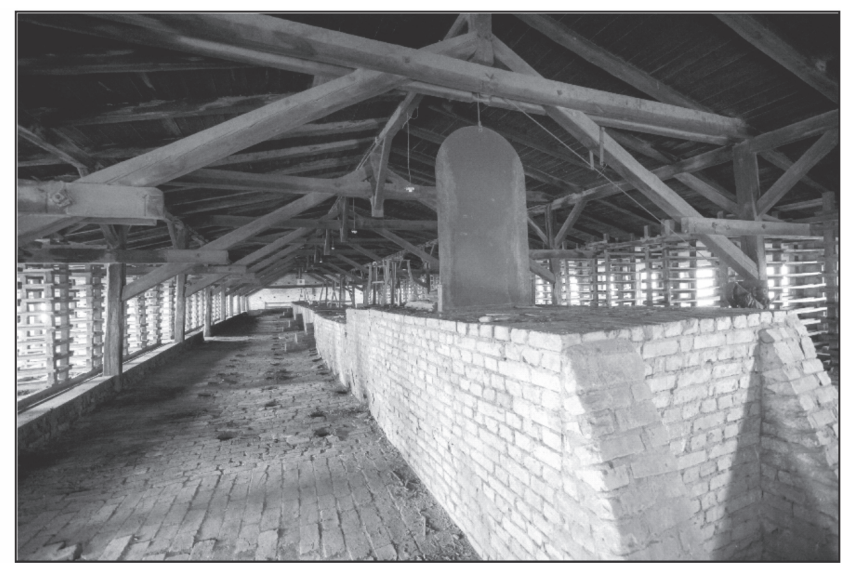

Fot. 4. Cegielnia w miejscowości Pudliszki, widok na górną część pieca (typ: piec typu „Hoffman”, widoczne są na zdjęciu czeluście zasypowe paliwa, „koniki” i właz umożliwiający regulację napływu powietrza, w tle konstrukcje umożliwiające suszenie cegieł)

fot. S. Staszewska

Wspólnie z mieszkańcami (przy ich zaangażowaniu i poparciu) został stworzony projekt zagospodarowania przestrzennego starej cegielni (ryc. 1). Mieszkańcy zostali włączeni w proces projektowy przy zastosowaniu metody facylitacji. Określili oni funkcje terenu, zaprezentowali na spotkaniach pomysły, które mogą przyczynić się do poprawy ich warunków zamieszkania. Zdecydowali, aby na terenie cegielni pojawiły się elementy zagospodarowania, które dadzą możliwość rozwoju rekreacyjnych i wypoczynkowych form. Na terenie całej gminy brak jest tego typu obiektów. Realizacja projektu ma się odbyć dwuetapowo: Etap 1 - adaptacja stawu na kąpielisko i stawu dla wędkarzy oraz zagospodarowanie terenów rekreacyjnych; Etap 2 - adaptacja, modernizacja i przebudowa obiektów budowlanych na cele edukacyjne i poznawcze. Projekt obejmuje: 1) urządzone strzeżone kąpielisko z plażą, małą gastronomią i wypożyczalnią sprzętu wodnego, 2) rekultywację i zabezpieczenie pierwszego stawu powyrobiskowego na cele rekreacyjne, 3) rekultywację i zabezpieczenie drugiego stawu powyrobiskowego z przeznaczeniem na łowisko, z wyeksponowaniem walorów krajobrazowych, 4) budowę parkingu dla samochodów osobowych, 5) organizację parku rekreacyjnego wraz z wytyczonymi ścieżkami do celów spacerowych i biegowych, 6) wytyczenie toru crossowego do jazdy rowerem, 7) udostępnienie terenu pod usługi małej gastronomii z tarasem widokowym na cegielnię. Projekt ma służyć społeczności gminy oraz ma znaczenie regionalne (turystyczne, rekreacyjne, wypoczynkowe, społeczne). Projekt obejmuje obiekty architektury krajobrazu 


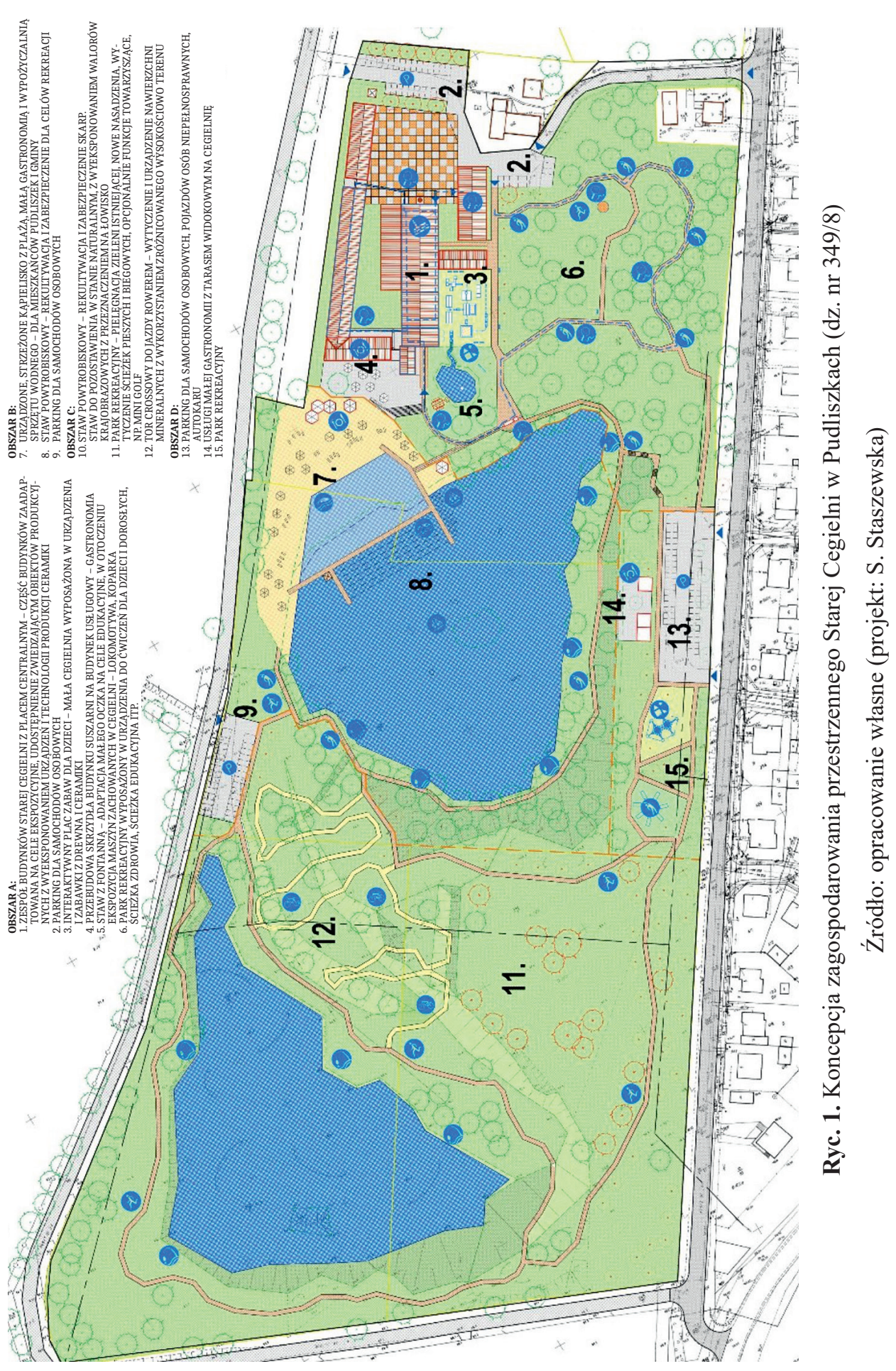


o charakterze obiektów użyteczności publicznej o dużym znaczeniu społecznym. Wymagał on szczególnych rozwiązań przyrodniczych, artystycznych, społecznych i inżynierskich. Możliwość wtórnego zagospodarowania terenów poprzemysłowych i rekultywacja terenów powyrobiskowych cegielni poszerzy także ofertę inwestycyjną gminy i może się przyczynić do rozwoju przedsiębiorczości. Projekt nie został jeszcze zrealizowany, jednak zaangażowanie w proces jego tworzenia, nadzieje zainicjowane wśród mieszkańców, ich identyfikacja z miejscem i pomysłowość jego wykorzystania dają olbrzymią szansę na jego realizację. Istniejący opuszczony zespół budynków (wraz z przestrzenią pomiędzy nimi) zamieniono w miejsce spotkań i integracji z możliwością prowadzenia działalności gospodarczej i z licznymi usługami spełniającymi potrzeby mieszkańców. Na wskazanym terenie ma powstać: 1) zespół budynków Starej Cegielni z placem centralnym (część budynków zaadaptowano na cele ekspozycyjne, z eksponowaniem urządzeń i technologii produkcji ceramiki), 2) parking dla samochodów osobowych, 3) interaktywny plac zabaw dla dzieci, 4) skrzydło budynku suszarni, które ma zostać przebudowane na budynek usługowy (gastronomiczny), 5) skwer wraz z fontanną, 6) park rekreacyjny wyposażony w urządzenia rekreacyjne dla dzieci i dorosłych. Projekt ma służyć społeczności gminy oraz ma znaczenie regionalne (turystyczne, społeczne, edukacyjne, dydaktyczne). Projekt dotyczy budowli o charakterze obiektów użyteczności publicznej o dużym znaczeniu społecznym. Efektami społecznymi zrealizowanego projektu będzie:

- rozwijanie wartości miejsc o wysokich walorach turystycznych i wypoczynkowo-rekreacyjnych,

- podniesienie warunków wypoczynku, rekreacji i spędzania czasu wolnego dla mieszkańców gminy Krobia i społeczności sąsiednich gmin,

- poprawa stanu środków finansowych gospodarstwa domowego, wskutek rozwoju przedsiębiorczości istniejącej i nowej,

- społeczne zaangażowanie w aktywizację terenu i usług wzmocni poczucie własnej wartości i wpłynie na aktywizację zawodową i gospodarczą mieszkańców,

- poprawa warunków wypoczynku mieszkańców poprzez wzmocnienie jakości nowopowstałych miejsc turystyczno-wypoczynkowych,

- dzięki udziałowi w projekcie, uczestnicy zdobędą wiedzę z zakresu zakładania i prowadzenia własnej działalności gospodarczej oraz przełamią bariery obawy przed otworzeniem własnego biznesu,

- nastąpi zwiększenie aktywności zawodowej mieszkańców, poprawa zamożności, ruchliwość przestrzenna osób i mienia.

Prezentowany powyżej przykład rewitalizacji wiejskiego terenu poprzemysłowego jest wyrazem zaangażowania mieszkańców i pełnego poparcia ze strony władz gminy Krobia. Wynika on z ich potrzeb i pragnień. Realizacja tego przedsięwzięcia spowoduje zmianę w krajobrazie wsi, uporządkuje teren, sprawi, że będzie aktywny społecznie i gospodarczo. Powierzchnia lasów i zadrzewień w gminie kształtuje się na poziomie 4\%, co ogranicza dostęp do terenów zieleni. Brak kąpie- 
lisk uniemożliwia aktywne spędzanie wolnego czasu. Teren starej cegielni w Pudliszkach to jedyny obszar o wartościach rekreacyjno-wypoczynkowych w gminie, umożliwiający (po realizacji projektu) aktywność ruchową i umysłową wszystkich grup społecznych, kontakty społeczne, będzie atrakcją turystyczną na skalę regionu, bowiem nie ma na terenie ziemi gostyńskiej obiektu o podobnej funkcji i stanie zainwestowania. Projekt jest obecnie w fazie realizacji.

Drugim przykładem innowacyjnych zmian w krajobrazie jest projekt zagospodarowania terenu zlokalizowanego przy świetlicy wiejskiej w Domachowie. Wieś ta liczy 269 osób (2016) i położona jest w gminie Krobia, w południowej części województwa wielkopolskiego, w krainie fizjograficznej Mezoregion Wysoczyzna Kaliska. Miejscowość z widocznym historycznym układem ruralistycznym, w której zwarty układ zabudowań koncentruje się wokół nieregularnego placu. Po zewnętrznym obrysie znajdują się dwie boczne drogi owalne, ułatwiające dostęp do pól i stodół. Najważniejszym jednak miejscem nie tylko dla mieszkańców wsi, ale także całego regionu jest świetlica wiejska i teren ją otaczający (fot. 5a i b).
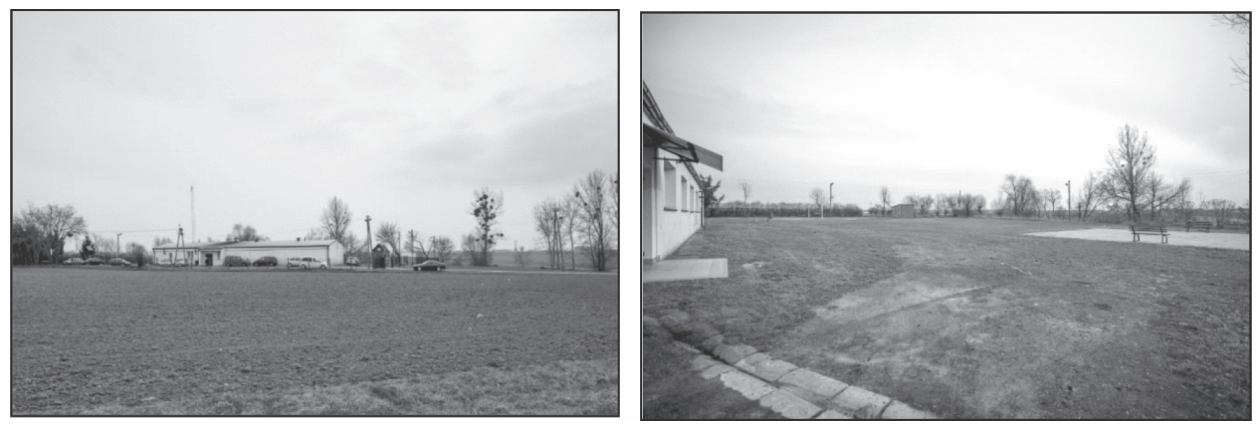

Fot. 5a i b. Świetlica wiejska we wsi Domachowo wraz z przyległym terenem. Tu odbywają się wszystkie cykliczne imprezy folklorystyczne skupiające duże grupy uczestników (nawet do 2000). Obiekt zaopatrzony w sanitariaty, kuchnię, dużą salę, sąsiaduje z nim rozległy nieuporządkowany teren

\section{fot. S. Staszewska}

Tu bowiem odbywają się rokrocznie Festiwale Tradycji i Folkloru. Jest to ponadto obiekt o charakterze terapeutycznym, edukacyjnym, rekreacyjnym, wykorzystujący tradycje i walory wsi. Podejmowane są tu działania służące pielęgnowaniu i promowaniu nie tylko folkloru biskupiańskiego, ale także wiejskiego życia i pracy. W obiekcie prowadzone są warsztaty tematyczne dla dzieci, młodzieży i dorosłych. Uczestnicy zajęć uczą się przyśpiewek i tańców regionalnych, przygotowują tradycyjne potrawy kulinarne na bazie przewodnika kulinarnego „Biskupizna ze smakiem" czy też biorą udział w zajęciach z rękodzielnictwa bądź hafciarstwa. Prowadzone są także lekcje regionalne, podczas których dzieci i młodzież poznają Biskupiznę, ucząc się elementów tradycyjnych tańców (wiwata, przodka), poznają instrumenty ludowe, a także uczestniczą w konkursie gwarowym. Świetlica 
wiejska to również miejsce spotkań, podczas których prezentowany jest folklor biskupiański, m.in. przez Biskupiański Zespół Folklorystyczny z Domachowa i okolic, Dziecięcy Zespół Biskupiański przy Przedszkolu Samorządowym „Pod Świerkami” w Krobi, Dziecięcy Zespół Biskupiański przy ZSPiG w Krobi czy Zespół Młodzi Biskupianie. Jest to miejsce wykorzystywane do wizyt gości z różnych stron kraju i świata oraz do organizacji konferencji i spotkań. „Tradycje kulturowe Biskupizny" zostały wpisane na Krajową Listę Niematerialnego Dziedzictwa Kultury prowadzoną przez Ministra Kultury i Dziedzictwa Narodowego.

Teren wokół świetlicy wiejskiej wymaga poprawy zagospodarowania, dzięki któremu możliwa byłaby właściwa organizacja festiwali, a spotkania mieszkańców będą skłaniały do jeszcze większej aktywności. Dlatego mieszkańcy tak chętnie zaangażowali się w proces tworzenia tego miejsca. Dzięki warsztatom przeprowadzonych metodą facylitacji, mieszkańcy samodzielnie określili sposób zagospodarowania terenu (ryc. 2). Dyskusja nad wariantami rozwiązań przestrzennych ustalonych podczas spotkań pozwoliła na sprecyzowanie wspólnego, akceptowalnego przez wszystkich projektu, uwzględniającego potrzeby różnych użytkowników i spełniającego ich wymagania (ryc. 3). W efekcie powstała propozycja przestrzennego rozkładu elementów zagospodarowania. To rozwiązanie stało się podstawą decyzji administracyjnych, finansowych i organizacyjnych władz gminy przy pełnej współpracy i poparciu mieszkańców.

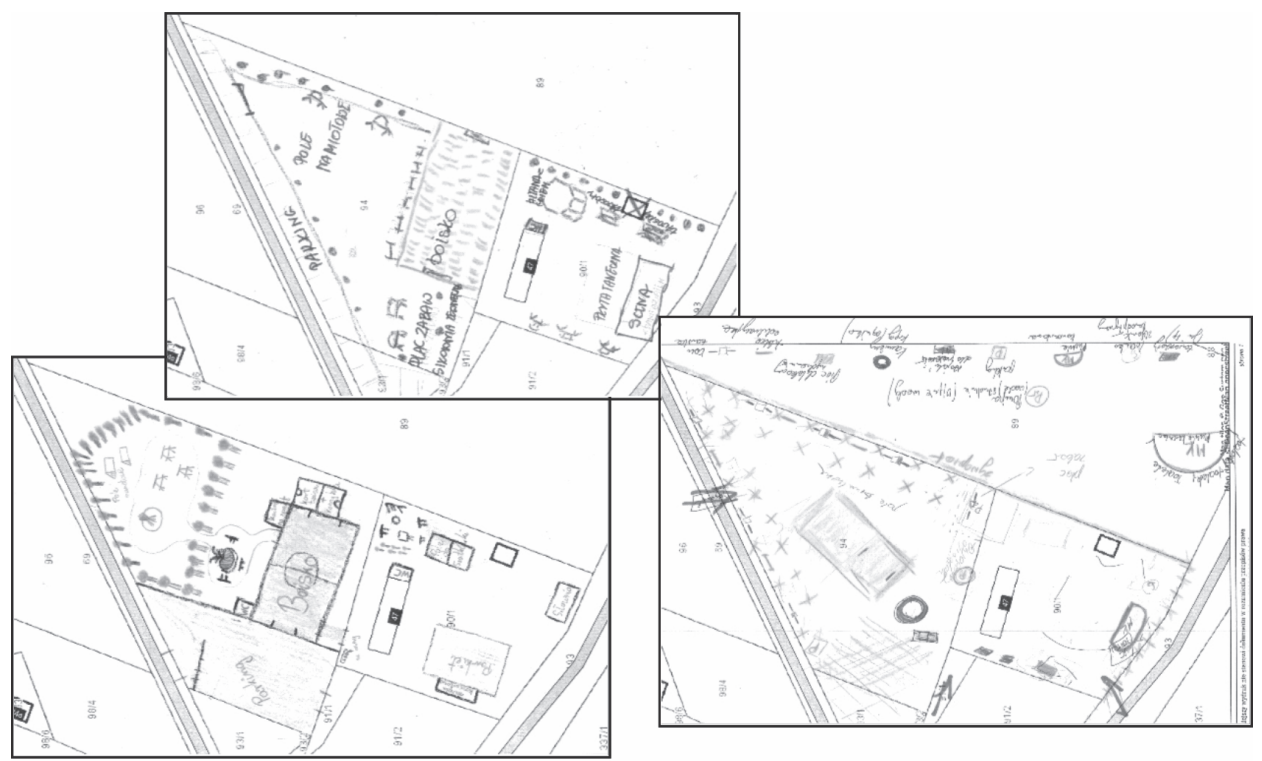

Ryc. 2. Propozycje zagospodarowania terenu przy świetlicy wiejskiej w Domachowie - efekt prac w procesie facylitacji (dz. nr 90/1, 91/1, 93/1, 2, 3, 94, obręb 0005)

Źródło: wybrane 3 z 7 koncepcji stworzonych podczas warsztatów facylitacyjnych, miejsce spotkań: świetlica wiejska w Domachowie 
Zgodnie z wolą uczestników warsztatów na wskazanym terenie ma powstać: 1) parking, 2) świetlica wiejska, 3) plac główny, 4) pawilony wielofunkcyjne, 5) plac do organizacji imprez plenerowych, 6) plac zabaw dla dzieci, 7) siłownia zewnętrzna, 8) boisko wielofunkcyjne, 9) pole namiotowe, 10) ścieżka edukacyjna oraz 11) scena z profesjonalnym wyposażeniem umożliwiającym taniec i występy. Projekt ma służyć społeczności gminy oraz ma znaczenie regionalne (turystyczne i społeczne). Efektami społecznymi zrealizowanego projektu będzie:

- rozwijanie i poprawa wiedzy przez mieszkańców na temat wartości kulturowych i kultury regionu,

- wzmacnianie i rozwijanie tożsamości poprzez odkrywanie potencjału kultury miejsca,

- wzmocnienie więzi rodzinnych i społecznych poprzez spotkania podczas festiwali, festynu, imprez plenerowych,

- budowa tożsamości lokalnej,

- aktywizacja mieszkańców i osób zewnętrznych poprzez czynny udział w atrakcjach i imprezach folklorystycznych i kulturowych.

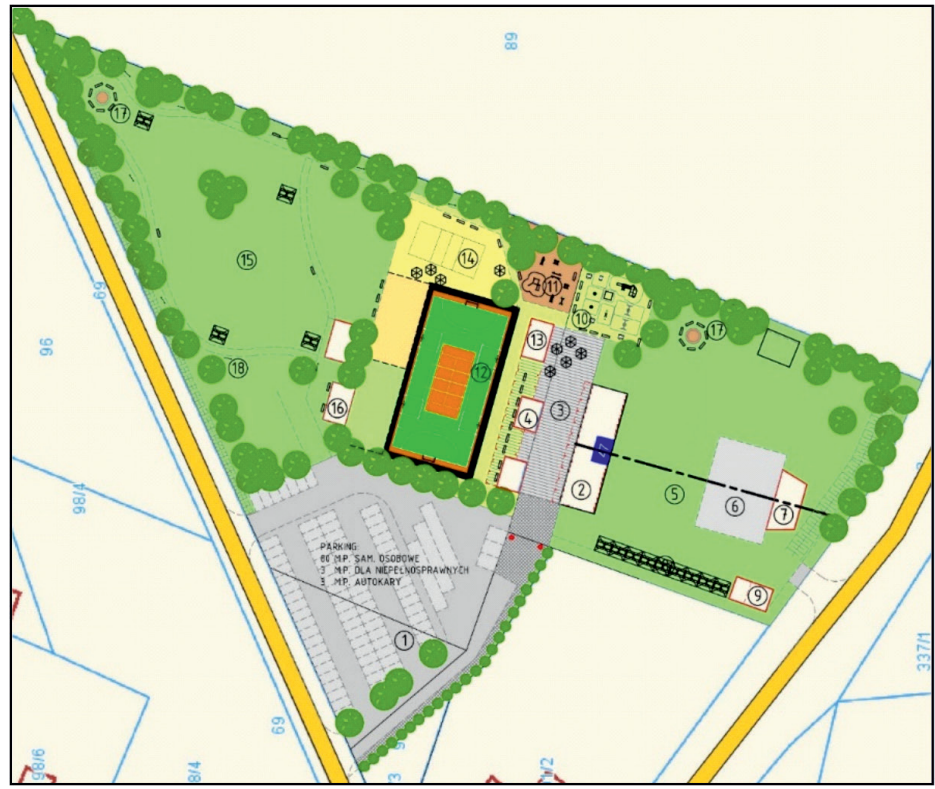

$$
\begin{aligned}
& \text { OBJAŚNIENIA NA RYSUNKU } \\
& 1 \text { PARKING } \\
& 2 \text { ŚWIETLICA WIEJSKA } \\
& 3 \text { PLAC GEÓWNY/UTWARDZONY/ } \\
& \text { BRUK Z OTOCZAKÓW } \\
& 4 \text { PAWILONY WIELOFUNKCYJNE } \\
& 5 \text { PLAC DO ORGANIZACJI IMPREZ } \\
& \text { PLENEROWYCH/ZIELONY } \\
& 6 \text { MIEJSCE UTWARDZNE DO ZABAW } \\
& 7 \text { SCENA } \\
& 8 \text { ŁAWOSTOEY } \\
& 9 \text { BUDYNEK ZAPLECZA/TOALETY/ } \\
& \text { POSIEKI } \\
& 10 \text { PLAC ZABAW DLA DZIECI } \\
& 11 \text { SIEOWNIA ZEWNĘTRZNA/ } \\
& \text { PLAC ZABAW DZIECI STARSZE } \\
& 12 \text { BOISKO WIELOFUNKCYJNE/MINI } \\
& \text { PIŁKA NOŻNA, KOSZ, PIŁKA } \\
& \text { RĘCZNA, TENIS, SIATKÓWKA } \\
& 13 \text { PAWILON ZAPLECZA BOISKA/ } \\
& \text { TOALETY } \\
& 14 \text { NP. BOISKO SIATKÓWKA PLAŻOWA/ } \\
& \text { NAWIERZCHNIA PIASZCZYSTA } \\
& 15 \text { POLE NAMIOTOWE } \\
& 16 \text { BUDYNEK ZAPLECZA POLA/ } \\
& \text { TOALETY/KUCHNIA POLOWA ITP. } \\
& 17 \text { MIEJSCE NA OGNISKO } \\
& 18 \text { ŚCIEŻKA EDUKACYJNA } \\
& \text { „PSZCZÓEKA” }
\end{aligned}
$$

Ryc. 3. Koncepcja zagospodarowania przestrzennego terenu przy świetlicy wiejskiej w Domachowie (dz. nr 90/1, 91/1, 93/1, 2, 3, 94, obręb 0005)

Źródło: opracowanie własne (projekt: mieszkańcy w procesie facylitacji, warsztaty prowadzone przez S. Staszewską; rysunek ostateczny architektoniczno-urbanistyczny zgodny z warunkami technicznymi i zasadami projektowymi: S. Staszewska) 
Prezentowane w tej części pracy rozwiązania przyczynią się do innowacyjnego przeobrażenia krajobrazu wsi. Projekt, którego celem jest poszukiwanie nowych, lepszych, efektywniejszych sposobów rozwiązywania problemów stanowi clou dobrych zmian. Na początku niniejszego artykułu ustalono rozumienie innowacji jako korzystną zmianę $\mathrm{w}$ obrębie przestrzennych i społecznych procesów kształtowania wsi. Zasugerowano również, że nie jest wymagane, aby zmiana ta była nowością na skalę światową, zaznaczono także, że nie musi to być nawet zmiana radykalna, może mieć ona jedynie charakter usprawniający. Tak też jest w obu prezentowanych przykładach. Sposób tworzenia projektów, twórczość pomysłodawców, ich zaangażowanie w proces zmian, chęć współpracy i dostosowanie się do form warsztatów oraz sposobu ich prowadzenia dało wyraz w prospołecznym i innowacyjnym charakterze przestrzennego zagospodarowania terenu. W obu przypadkach następuje zmiana $\mathrm{w}$ krajobrazie wsi, jest ona innowacyjna, gdyż bardzo rzadko w procesie projektowym biorą udział mieszkańcy, bardzo rzadko sami tworzą, wymyślają, ustalają lokalizację elementów zagospodarowania. Oczywiście proces ten wymaga kontroli i opieki eksperckiej (technicznej, organizacyjnej, społeczno-psychologicznej), jednak efekt pracy daje dużą szansę na realizację. Mieszkańcy nie tylko w pełni akceptują zmiany, ale też sami uczestniczą (w sposób fizyczny) w pracach nad usprawnieniem ich życia i zamieszkania.

\section{Podsumowanie}

Innowacyjne przeobrażenia krajobrazu wsi wynikają zarówno z wyzwań i problemów rozwoju obszarów wiejskich, jak również zależą od czynników inicjujących i warunkujących zmiany w ich strukturze. Te jednak wpływają na zmiany pośrednio, głównie poprzez inwestycyjne decyzje władz, poprzez ustalenia w przepisach prawa miejscowego lub są wyrażone w treści dokumentów administracyjnych bądź strategicznych. Niestety, bardzo rzadko w proces projektowy włączani są mieszkańcy. Choć mają możliwość zgłaszania uwag jakiegoś dokumentu w czasie konsultacji społecznych, to prawie nigdy nie są członkami grupy projektowej czy decyzyjnej. Choć władze gminy często pytają swoich mieszkańców o ich potrzeby, to z ogromu spraw zgłaszanych przez mieszkańców do realizacji wybierane są te mniej kosztochłonne, o krótkim czasie inwestycji, politycznie poprawne. Wynika to pewnie z faktu, iż każdy mieszkaniec zgłaszałby projekt w oparciu o indywidualne potrzeby, nie patrząc na wartości ogółu. Tym niemniej projekty miejsc uzasadnionych społecznie, hierarchicznie ważnych, spełniających potrzeby większości lokalnego społeczeństwa powinny być współtworzone przez samych mieszkańców. Ważne, by ów proces odbywał się w sposób uzasadniony i był przeprowadzany w sposób fachowy. Te metody czy techniki, które angażują w projekty i przedsięwzięcia, które zwiększają efektywność zespołu, budują 
współodpowiedzialność za cele i efekt, integrują osoby o odmiennych priorytetach i interesach, zmieniają odtwórców w kreatorów, można nazwać innowacyjnymi. Niewątpliwie taką metodą jest facylitacja prezentowana w niniejszym artykule, każda jednak inna technika angażująca mieszkańców w tworzenie miejsc w sposób nowatorski może spowodować zmiany wyjątkowe i społecznie akceptowalne, a wtedy nastąpi innowacyjne przeobrażenie krajobrazu wsi.

\section{Literatura}

Bajerowski T., 2003, Podstawy teoretyczne gospodarki przestrzennej i zarządzania przestrzenia, Wydawnictwo Uniwersytetu Warmińsko-Mazurskiego, Olsztyn.

Bielski I., 2000, Przebieg i uwarunkowania procesów innowacyjnych, OPO, Bydgoszcz.

Chmielewski T.J., 2001, Systemy planowania przestrzennego harmonizującego przyrode i gospodarke, Wydawnictwo Politechniki Lubelskiej, t. 1: 1-294, t. 2: 1-143.

Chmielewski T.J., 2009, Przyszłość systemu ekologicznego Polski, „Problemy Ekorozwoju", 4(2): 73-82.

Chodyński A., 2013, Przedsiębiorczość i innowacyjność a kompetencje - aspekty strategiczne, www.sbc.org.pl/Content/19373/chodynski.pdf (dostęp: 15.03.2013).

Crow M., Bozeman B., 1998, Strategic Public Management, [w:] Bryson J.M., Einsweile R.C. (red.), Strategic Planning Threats and Opportunities for Planners, American Planning Association, Chicago.

Czapiewska G., 2014, Wspótczesne wyzwania i zagrożenia rozwoju obszarów wiejskich Pomorza, „Nierówności Społeczne a Wzrost Gospodarczy”, 38(2).

Fagiewicz K., 2010, Zasoby wodne aglomeracji poznańskiej i problematyka ich ochrony, [w:] Mizgajski A. (red.), Zasoby przyrodnicze i ich ochrona w aglomeracji poznańskiej, Biblioteka Aglomeracji Poznańskiej, nr 2, Centrum Badań Metropolitalnych, UAM, Bogucki Wydawnictwo Naukowe, Poznań: 59-79.

Falkowski J., 2014, Wielofunkcyjność i próba wyróżnienia funkcjonalno-gospodarczych typów krajobrazu wiejskiego Polski, „Studia Obszarów Wiejskich”, 35, PTG, IGiPZ PAN, Warszawa: 9-28.

Falkowski J., 2015, Geografia wsi - próba ujęcia systemowego, „Studia Obszarów Wiejskich", 37, PTG, IGiPZ PAN, Warszawa: 91-114.

Główka G., 2010, Finansowanie inwestycji jednostek samorządu terytorialnego kredytem bankowym, „Ekonomika i Organizacja Gospodarki Żywnościowej. Zeszyty Naukowe SGGW", 80, Warszawa.

Griffin R.W., 1998, Podstawy zarzadzania organizacjami, Wydawnictwo Naukowe PWN, Warszawa.

Jezierska-Thöle A., Biczkowski M. (red.), 2014, Zintegrowany rozwój obszarów wiejskich w świetle polityki Unii Europejskiej, t. 2: Wielofunkcyjność obszarów wiejskich, Wydawnictwo Naukowe UMK, Torun.

Kalinowska A., 1993, Ekologia - wybór przyszłości, Editions Spotkania, Warszawa.

Knieć W., 2010, Partnerstwa lokalne w Polsce - kondycja, struktura, wyzwania. Raport badawczy, Fundacja Partnerstwo dla Środowiska, Kraków-Torun.

Kopańska A., Witkowski K., 2003, Zewnętrzne źródła finansowania inwestycji jednostek samorząu terytorialnego, Wydawnictwo Difin, Warszawa. 
Kowalczyk A., Derek M., 2010, Zagospodarowanie turystyczne, Wydawnictwo Naukowe PWN, Warszawa.

Lechio J., Kulczyk S., Malinowska E., Szumacher I., 2008, Klasyfikacja krajobrazu. Teoria i praktyka, „Problemy Ekologii Krajobrazu”, 20, Polska Asocjacja Ekologii Krajobrazu, Wydział Geografii i Studiów Regionalnych Uniwersytetu Warszawskiego, Warszawa.

Leńkowa A., 1978, Zarys historii ochrony przyrody, [w:] Mihajłow W., Zabierowski K. (red.), Ochrona i kształtowanie środowiska przyrodniczego, Zakład Ochrony Przyrody PAN, Kraków, Państwowe Wydawnictwo Naukowe, Warszawa: 137-186.

Lisowski A., 2006, Potrzeby społeczne $i$ ich diagnozowanie, Biblioteka Narodowa, Warszawa.

Łuszczek M., Ptasińska U. (red.), Jak tworzyć miejsce? Podręcznik kreowania udanych przestrzeni publicznych, Fundacja Partnerstw dla Środowiska, Kraków.

Meadows D.H., Meadows D.L., Randers J., 1992, Beyond the Limits. Global Colaps or a Sustainable Future, Earthscan Publications Limited, International Institute for Environment and Development, World Wilde Fund of Nature, London.

Nowakowska A., 2011, Regionalny wymiar procesów innowacji, Wydawnictwo Uniwersytetu Łódzkiego, Łódź.

Ossowicz T., Zipser T. (red.), 2006, Urbanistyka w działaniu: teoria i praktyka, Urbanista, Warszawa.

Pawłowska K., 2010, Zanim wybuchnie konflikt. Idea i metody partycypacji społecznej w ochronie krajobrazu i ksztattowaniu przestrzeni, Fundacja Partnerstw dla Środowiska, Kraków.

Rydz E., Rudnicki R. (red.), 2009, Procesy przekształceń przestrzeni wiejskiej, „Studia Obszarów Wiejskich", 17, PTG, IGiPZ PAN, Warszawa.

Rylke J., 1978, Stosunek człowieka do krajobrazu w różnych okresach ludzkiej aktywności, „Aura”, 12: 7-8.

Skalski J.A., 2007, Analiza percepcyjna krajobrazu jako działalność twórcza inicjująca proces projektowania, Wydawnictwo SGGW, Warszawa.

Staszewska S., 2013, Urbanizacja przestrzenna strefy podmiejskiej polskiego miasta, Bogucki Wydawnictwo Naukowe, Poznań.

Szafer W., 1965, Zarys historii ochrony przyrody w Polsce, [w:] Szafer W. (red.), Ochrona przyrody i jej zasobów, „Problemy i Metody”, 1, Zakład Ochrony Przyrody PAN, Kraków: 53-123.

Wolski P., Piwowarski M., 1998, Naturalizm funkcjonalny w sztuce ksztattowania ogrodów i krajobrazu, [w:] Wolski P. (red.), Ochrona dziedzictwa przyrodniczo-kulturowego w Polsce, Wydawnictwo SGGW, Warszawa: 37-46.

Wójcik M., 2013, Przemiany społeczno-przestrzenne osiedli wiejskich, Wydawnictwo Uniwersytetu Łódzkiego, Łódź.

Wyszkowska Z., 2012, Uwarunkowania rozwoju przedsiębiorczości na obszarach wiejskich, ,Journal of Agribusiness and Rural Development”, 3(25): 299-307.

Zajda K., 2015, Wieś jako terytorium innowacyjne, „Wieś i Rolnictwo”, 3(168): 7-19.

Zipser T., 2006, Teoria i praktyka w zakresie edukacji kadr dla gospodarki przestrzennej, [w:] Kudłacz T. (red.), Teoria i praktyka w zakresie edukacji kadr dla gospodarki przestrzennej, „Biuletyn KPZK PAN”, 224: 8-15. 
Zrobek J., 2014, Innowacyjne aspekty rozwoju obszarów wiejskich, „Handel Wewnętrzny", 5(352): 333-345.

Zuziak Z., 2008, O tożsamości urbanistyki, Wydawnictwo Politechniki Krakowskiej, Kraków.

Żarska B., 2006, Modele ekologiczno-przestrzenne i zasady ksztattowania krajobrazu gmin wiejskich, Wydawnictwo SGGW, Warszawa.

Żukrowska K., 2000, Konkurencyjność systemowa w procesie transformacji. Przykład Polski, [w:] Bossak J., Bieńkowski W. (red.), Konkurencyjność gospodarki Polski w dobie integracji z Unią Europejska i globalizacji, Szkoła Główna Handlowa, Warszawa.

\title{
Akty prawne
}

Ustawa z dnia 8 marca 1990 roku o samorzadzie gminnym (Dz.U., 1990, poz. 594).

Ustawa z dnia 27 marca 2003 roku o planowaniu i zagospodarowaniu przestrzennym (Dz.U., 2003, nr 80, poz. 717, z późn. zm.).

Ustawa z dnia 20 lutego 2015 roku o wspieraniu rozwoju obszarów wiejskich z udziałem środków Europejskiego Funduszu Rolnego na rzecz Rozwoju Obszarów Wiejskich w ramach Programu Rozwoju Obszarów Wiejskich na lata 2014-2020 (Dz.U., 2017, poz. 562, z późn. zm.).

\section{INNOVATIVE COUNTRYSIDE LANDSCAPE TRANSFORMATIONS - FACTORS AND EFFECTS}

\begin{abstract}
Rarely do the ladscape changes stem from the needs, demands or preferences of the local communities. The conceptions of area spacious development are performed by the specialists who, of course, consult the effects of their work with inhabitants, but still ideas are not creative expressions of the direct users in a partictular area.but of the designers.

In this work the author would like to present the innovative way of the designing process leading to the innovative changes in the countryside landscape. This aim is executed gradually. First, the notion of innovativess has been explained (in order to subsume the case study in its meaning). Then challenges and problems of rural areas development being the need of innovative changes have been indicated. Next, the initiating factors and the factors qualifying innovative transformations of the countryside landscapehave been indicated because they should be perceived as the base of transformation, and finally, in order to show the effects of innovative transformations of the countryside landscape being the result of facilitating workshops conducted in 2017 in the chosen villages of Krobia borough (Greater Poland Voivodeship), i.e. Pudliszki and Domachowo.
\end{abstract}

Keywords: countryside transformation factors, effects of countryside landscape changes, innovative designing.

Dr hab. inż. Sylwia Staszewska, prof. nadzw. UAM Instytut Geografii Społeczno-Ekonomicznej i Gospodarki Przestrzennej Wydział Nauk Geograficznych i Geologicznych

Uniwersytet im. Adama Mickiewicza w Poznaniu e-mail: sylwia.staszewska@amu.edu.pl 